\title{
A Study of Nitrous oxide Emission from Rice Fields in Tarai Region of Uttarakhand, India
}

\author{
P.P. Singh ${ }^{1}$, Rashmi Pawar ${ }^{2}$ and R. Meena ${ }^{3} *$ \\ ${ }^{1}$ Deptartment of Agromateorology, JNKVV, Jabalpur (M.P.), India \\ ${ }^{2}$ Department of Horticulture, G.B. pant University of Agriculture and Technology, Pantnagar, \\ Uttarakhand, India \\ ${ }^{3}$ Department of Soil Science and Agricultural Chemistry, Institute of Agricultural Sciences, \\ Banaras Hindu University, Varanasi- 221005 (U.P.), India \\ *Corresponding author
}

A study was conducted at Crop Research Center of G.B. pant University of Agriculture and Technology, Pantnagar in Tarai region of Uttarakhand, India to quantify nitrous oxide emission from rice fields due to the addition of different organic amendments and

\section{Keywords}

Oxide flux, Growth stages, Rice crop, Methane emission, Nitrous oxide emission.

\section{Article Info}

Accepted:

02 March 2017

Available Online:

10 April 2017 inorganic fertilizers. The average nitrous fluxes for rice were $0.57,1.87,2.37,3.52$ and $1.27 \mathrm{mg} \mathrm{m}^{-2} \mathrm{~h}^{-1}$ from control with crop, farmyard manure (FYM), green manure (GM), straw amendments and sulphur fertilizers, respectively. Among different growth stages of rice transplanting to tillering growth stage nitrous oxide flux was maximum in straw amendment, $5.79 \mathrm{mg} \mathrm{m}^{-2} \mathrm{~h}^{-1}$ while lowest in control $0.53 \mathrm{mg} \mathrm{m}^{-2} \mathrm{~h}^{-1}$. After that, during tillering highest flux was $3.58 \mathrm{mg} \mathrm{m}^{-2} \mathrm{~h}^{-1}$, with lowest in control $0.79 \mathrm{mg} \mathrm{m}^{-2} \mathrm{~h}^{-1}$. During reproductive to ripening growth stage nitrous oxide flux was highest in straw amendments, $2.72 \mathrm{mg} \mathrm{m}^{-2} \mathrm{~h}^{-1}$, followed by GM amendments, $2.47 \mathrm{mg} \mathrm{m}^{-2} \mathrm{~h}^{-1}$, FYM amendments, 1.47 $\mathrm{mg} \mathrm{m}^{-2} \mathrm{~h}^{-1}$, sulphurus fertilizers $0.95 \mathrm{mg} \mathrm{m}^{-2} \mathrm{~h}^{-1}$, and the lowest was in control with crop, $0.35 \mathrm{mg} \mathrm{m}^{-2} \mathrm{~h}^{-1}$. Lastly ripening to maturity growth stage nitrous oxide flux was highest in GM amendments, $1.69 \mathrm{mg} \mathrm{m}^{-2} \mathrm{~h}^{-1}$, followed by FYM amendments, $1.18 \mathrm{mg} \mathrm{m}^{-2} \mathrm{~h}^{-1}$, straw amendments, $0.42 \mathrm{mg} \mathrm{m}^{-2} \mathrm{~h}^{-1}$, sulphurus fertilizer, $0.43 \mathrm{mg} \mathrm{m}^{-2} \mathrm{~h}^{-1}$, and the lowest was in control with crop, $0.38 \mathrm{mg} \mathrm{m}^{-2} \mathrm{~h}^{-1}$. The results indicated that nitrous oxide emission was enhanced by undecomposed organic amendments (straw and green manure) as compared to well-decomposed organic amendments (farmyard manure) and sulphurus fertilizers.

\section{Introduction}

Nitrous oxide is an important green house gas and its concentration in atmosphere was estimated as $2.68 \times 10^{-2} \mathrm{~mL} \mathrm{~L}^{-1}$ around 1750 . It has increased by about $17 \%$ as a result of human alterations in the global $\mathrm{N}$ cycle (IPCC, 2001). Nitrous oxide has much greater global warming potential than $\mathrm{CO}_{2}$. When $\mathrm{N}_{2} \mathrm{O}$ reaches the stratosphere, most of it is converted to $\mathrm{N}_{2}$ through photolytic reaction that converts $\mathrm{O}_{3}$ into $\mathrm{O}_{2}$ thereby causing the stratosphere to lose some of its shielding properties against ultra violet rays (Schlesinger, 1997). Nitrous oxide forms in soils primarily during the process of gentrification (Robertson and Tiedje, 1987) and, to a lesser extent, during nitrification 
(Tortoise and Hutchinson, 1990). Global annual $\mathrm{N}_{2} \mathrm{O}$ emissions from agricultural soils have been estimated to range between 1.9 and 4.2 $\mathrm{Tg} \mathrm{N}$, with about half arising from anthropogenic sources (IPCC, 2001). The major factor controlling the flux of $\mathrm{N}_{2} \mathrm{O}$ are partial oxygen pressure, soil water status and flooding chemical status of the soil and land use. Nitrous oxide emission of paddy fields at different location in Taiwan was found between 0.20 to $0.17 \mathrm{mg} \mathrm{m}^{-2}$ in second crop season. Nitrous oxide emission in first crop season was higher than those in the second crop season because of intermittent irrigation and high temperature at the later growth stage.

\section{Materials and Methods}

The experiment was conducted in Kharif season on the Haldi loam soil, which is derived from calcareous alluvium from Shiwalik Mountains. The water table is shallow. The physico-chemical properties of soil are given in Table 1.

\section{Layout and treatment}

The experiment was conducted with five treatments and four replications in randomized block design. The treatments were $\mathrm{T}_{1}$ - Control with, $\mathrm{T}_{2-} 100 \% \mathrm{NPK}+$ FYM, T $3-100 \%$ NPK + GM, T $4^{-} 100 \%$ NPK + Straw and $\mathrm{T}_{5^{-}}-100 \%$ NPK + Sulphur. FYM and GM mean farmyard manure and green manure, respectively. The $100 \%$ NPK recommended dose for rice was $150: 60: 40 \mathrm{~kg}$ $\mathrm{ha}^{-1}$. The nitrogen provided by FYM, GM and Straw was subtracted from $150 \mathrm{~kg} \mathrm{~N}$ and remaining nitrogen was applied through urea. The nitrogen content of organic amendments is given in table 2 . In treatment $\mathrm{T}_{5}, \mathrm{NPK}$ were given through sulphur containing fertilizers like ammonium sulphate, single super phosphate and potassium sulphate and through, zinc sulphate.

\section{Rice field preparation and transplanting}

Harrowing was done twice with the help of harrow and puddling was done with the help of tractor- mounted puddler to prepare the field for rice transplanting. Twenty one days old seedling of rice variety pant Dhan-4 were transplanting at the rate of 2 seedlings per hill. The spacing among hills was $10 \times 20 \mathrm{~cm}$. Half dose of nitrogen as per treatment and full dose of phosphorous and potassium were applied as basal dressing during field preparation and pudding and mixed well in the soil remaining half of nitrogen was applied

\section{Collection of gas sample}

Gas samples were collected by closed character technique described by Hutchinson and Mosier (1981). Boxes made of acrylic sheets, having dimensions of $50 \times 30 \times 100 \mathrm{~cm}$ were used for taking the gas samples from plots. An aluminum channel was pre inserted in the field and water was filled in channel, whenever the chamber was placed for collecting the samples to make the set airtight. One mediflex three ways top cock (Eastern Medikit Ltd., India) was fitted at the top of chamber to collect gas samples. Three replicate gas samples were taken from each plot. Height of the headspace was taken for flux calculation.

\section{Analysis of gas sample}

The concentration of nitrous oxide was estimated through ECD (Electron Capture Detector), fitted with Porapak $\mathrm{N}$ stainless steel column. The temperature for column, injector and detector were kept at 45,120 and $300{ }^{0} \mathrm{C}$, respectively and the pressure of carrier gas (nitrogen) was $5.0 \mathrm{~kg} / \mathrm{cm}^{2}$. The peak area was measured with microprocessor controlled Nucon 5765 series gas chromatograph with integrator connected to computer. Pre-calibrated standards of nitrous 
oxide (Scott specialty gas standard, imported and supplied by M/S Sigma- Aldrich) was used. The area of standard nitrous oxide peak was used to calculate the nitrous oxide concentration in the unknown gas sample peaks.

\section{Measurement of nitrous oxide flux}

Standard curves were made from the standard samples of know concentrations. Then gas samples gas of unknown concentrations were injected and the peak areas were noted. Using the peak area value and the standard, the concentrations values were taken. To measure flux, the chamber fixed at the experimental site and the change in concentrations in the chamber so formed, with time, was determined by taking triplicate gas samples from the chamber headspace by syringe and transported them to the laboratory for analysis.

\section{Calculation of nitrous oxide flux}

The nitrous oxide flux (F) was calculated using the following equation (Mitra et al., 1999).

$\mathrm{F}=\quad\left[\left(\mathrm{C}_{1}-\mathrm{C}_{\mathrm{O}}\right) / \mathrm{t}\right] \times \mathrm{H} \times 117.85 \mathrm{mg} \mathrm{m}^{-2} \mathrm{~h}^{-1}$

Where $\mathrm{t}$ is time (minute), initial concentration (ppmv), $\mathrm{C}_{\mathrm{t}}$ is final concentration (ppmv), and $\mathrm{H}$ is height of head space $(\mathrm{m})$. The derivation of above equation will be as:

Cross sectional area of the chamber

$$
=\quad \mathrm{A} \mathrm{m}^{2}
$$

Height of head space

$$
=\mathrm{H} \mathrm{m}
$$

Volume of head space

$$
=\quad \mathrm{A} \mathrm{H} \mathrm{m}^{3}
$$

$\mathrm{N}_{2} \mathrm{O}$ concentration at 0 time

$$
=\quad \mathrm{C}_{\mathrm{o}} \mathrm{ppmv}
$$

$\mathrm{N}_{2} \mathrm{O}$ concentration after time $\mathrm{t}$

$$
=\quad \mathrm{C}_{\mathrm{t}} \mathrm{ppmv}
$$

Change in Concentration in time $\mathrm{t}$

$$
\begin{aligned}
& =\quad\left(\mathrm{C}_{\mathrm{t}}-\mathrm{C}_{\mathrm{o}}\right) \mathrm{ppmv} \\
& =\quad\left(\mathrm{C}_{\mathrm{t}}-\mathrm{C}_{\mathrm{o}}\right) \mu \mathrm{L} / \mathrm{L}
\end{aligned}
$$

Volume of $\mathrm{N}_{2} \mathrm{O}$ emitted in time $\mathrm{t}$

$$
\begin{aligned}
& =\quad\left(\mathrm{C}_{\mathrm{t}}-\mathrm{C}_{\mathrm{o}}\right) 1^{1} \times 1000 \times \mathrm{AHL} . \\
& =\quad\left(\mathrm{C}_{\mathrm{t}}-\mathrm{C}_{\mathrm{o}}\right) \times \mathrm{AH} \mathrm{mL} .
\end{aligned}
$$

When $t$ is in minutes then flux $(\mathrm{F})$

$$
\begin{array}{ll}
= & {\left[\left\{\mathrm{C}_{\mathrm{t}}-\mathrm{C}_{\mathrm{o}}\right) \times \mathrm{AH}\right] /(\mathrm{A} \times \mathrm{t}) \mathrm{mLm}^{-2} \mathrm{~min}^{-1}} \\
= & \mathrm{Y} \mathrm{mL} \mathrm{m}^{-2} \min ^{-1} \\
= & \mathrm{C}_{\mathrm{t}}-\mathrm{C}_{\mathrm{o}} \times \mathrm{H} \mathrm{t}
\end{array}
$$

If $\mathrm{Y}$

Then flux nitrous oxide

$$
=\mathrm{Y} \times 44 / 22400 \mathrm{gm}^{-2} \mathrm{~min}^{-1}
$$

Because $1 \mathrm{~mL}$ of nitrous oxide

$$
=\quad 44 / 22400 \mathrm{~g}
$$$$
=\quad \mathrm{Y} \times 44 / 22400 \times 1000 \times 60 \mathrm{mg} \mathrm{m}^{-2}
$$

$\mathrm{h}^{-1}$

Hence, F

$$
=\quad \mathrm{C}_{\mathrm{t}}-\mathrm{C}_{\mathrm{o}} \times \mathrm{H} \times 117.857 \mathrm{mg} \mathrm{m}^{-2} \mathrm{~h}^{-1} \mathrm{t}
$$

\section{Results and Discussion}

Nitrous oxide flux measurement was carried out up to eighty- two days after transplanting and started from ten days after transplanting of rice. The data on nitrous oxide emission are presented in table 3 . The Nitrous oxide emission over the seventy two days period from rice crop was $109.1,355.6,450.9,668.5$ and $242.2 \mathrm{~g} \mathrm{ha}^{-1}$ in control with crop, $100 \%$ NPK + FYM, 100\% NPK +GM, 100\% NPK + Straw and $100 \%$ NPK + Sulphur treatments. This indicated that highest nitrous oxide emission was in straw treated plots. This is because the addition of un-decomposed organic amendments enhances the nitrous oxide emission. Different growth stages of rice also play an important role in the nitrous oxide emission (Figure 1). It was found that during tillering stage the nitrous oxide flux was maximum in straw amendment i.e. 5.79 $\mathrm{mg} \mathrm{m}^{-2} \mathrm{~h}^{-1}$ followed by GM amendment i.e. 
$1.45 \mathrm{mg} \mathrm{m}^{-2} \mathrm{~h}^{-1}$, FYM amendment (1.60) mg $\mathrm{m}^{-2} \mathrm{~h}^{-1}$, sulphurus fertilizers oxide emission during tillering stage is mainly due to higher vegetative growth of rice crop. Similarly, panicle initiation stage the nitrous oxide flux was highest in straw amendment (3.58) followed GM (2.74), FYM (2.53), sulphurus fertilizers (1.78) and the lowest in control with crop $\left(0.79 \mathrm{mg} \mathrm{m}^{-2} \mathrm{~h}^{-1}\right)$. During reproductive stage the nitrous oxide flux was in highest straw amendments (2.52) followed by FYM (2.28), GM (2.24) sulphurus fertilizers (1.47) and lowest was in control with crop $\left(0.62 \mathrm{mg} \mathrm{m}^{-2} \mathrm{~h}^{-1}\right)$ During ripening stage the nitrous oxide flux was $2.72 \mathrm{mg} \mathrm{m}^{-2}$ $\mathrm{h}^{-1}$ in straw amendment followed by GM (2.47), FYM (1.47), sulphurus fertilizers (0.95) lowest was in control with crop amendment $\left(0.35 \quad \mathrm{mg} \quad \mathrm{m}^{-2} \quad \mathrm{~h}^{-1}\right)$ During maturing stage the highest nitrous oxide flux was observed in GM amendment (1.69) followed by FYM (1.18), sulphurus fertilizers (0.43), straw (0.42) and lowest was in control with crop i.e., $0.38 \mathrm{mg} \mathrm{m}^{-2} \mathrm{~h}^{-1}$.

Table.1 Physico-chemical properties of initial soil

\begin{tabular}{lcc}
\hline \multicolumn{1}{c}{ Property } & Soil depth \\
\hline & $\mathbf{0 - 1 5} \mathbf{~ c m}$ & $\mathbf{1 5 - 3 0 ~ c m ~}$ \\
$\mathrm{EC}\left(\mathrm{d} \mathrm{Sm}^{-1}\right)$ & 0.10 & 0.11 \\
$\mathrm{Soil} \mathrm{p}^{\mathrm{H}}(1: 2)$ & 7.74 & 7.87 \\
Organic carbon $(\%)$ & 1.10 & 0.82 \\
Available nitrogen $\left(\mathrm{kg} \mathrm{ha}^{-1}\right)$ & 172.5 & 106.6 \\
Available phosphorous $\left(\mathrm{kg} \mathrm{ha}^{-1}\right)$ & 31.4 & 12.5 \\
Available potassoum $\left(\mathrm{kg} \mathrm{ha}^{-1}\right)$ & 241.9 & 156.8 \\
\hline
\end{tabular}

Table.2 Nitrogen content of organic amendments

\begin{tabular}{lcc}
\hline \multicolumn{1}{c}{ Organic Amendment } & Nitrogen Content(\%) & $\begin{array}{c}\text { Nitrogen provided to soil } \\
\left(\mathbf{k g ~ h a}^{\mathbf{- 1}}\right)\end{array}$ \\
\hline FYM & 0.50 & 50 \\
Green Manure & 0.49 & 49 \\
Wheat Straw & 0.53 & 53 \\
\hline
\end{tabular}


Table.3 Effect of organic and inorganic sources of nutrients on nitrous oxide gas emission from rice field at different stage

\begin{tabular}{|c|c|c|c|c|c|}
\hline Days after Transplanting (DAT) & $\begin{array}{c}\mathrm{T}_{1} \\
\text { (Control with } \\
\text { crop) }\end{array}$ & $\begin{array}{c}\mathbf{T}_{2} \\
(\mathbf{1 0 0 \%} \\
\mathrm{NPK}+\mathbf{G M})\end{array}$ & $\begin{array}{c}\mathbf{T}_{\mathbf{3}} \\
(\mathbf{1 0 0 \%} \\
\mathrm{NPK}+\mathbf{G M}) \\
\end{array}$ & $\begin{array}{c}\mathrm{T}_{4} \\
(100 \% \text { NPK + } \\
\text { Straw })\end{array}$ & $\begin{array}{c}\mathrm{T}_{5} \\
\text { (100\% NPK+ } \\
\text { Sulphur) } \\
\end{array}$ \\
\hline 10 & 0.23 & 1.12 & 1.33 & 1.97 & 0.56 \\
\hline 14 & 0.76 & 2.66 & 2.96 & 7.36 & 1.67 \\
\hline 18 & 0.58 & 2.54 & 2.68 & 7.19 & 1.60 \\
\hline 22 & 0.29 & 2.23 & 2.70 & 7.34 & 1.50 \\
\hline 26 & 0.76 & 0.42 & 2.72 & 7.10 & 1.26 \\
\hline 30 & 0.62 & 0.61 & 2.28 & 3.75 & 1.14 \\
\hline Average flux up to Tillering stage & 0.54 & 1.60 & 2.45 & 5.79 & 1.29 \\
\hline 34 & 0.57 & 0.81 & 1.93 & 3.41 & 1.42 \\
\hline 38 & 0.42 & 1.01 & 1.09 & 3.40 & 1.65 \\
\hline 42 & 1.02 & 3.31 & 3.87 & 4.77 & 2.07 \\
\hline 46 & 1.28 & 4.76 & 3.89 & 4.66 & 2.00 \\
\hline 50 & 0.67 & 2.76 & 2.92 & 1.65 & 1.75 \\
\hline Average flux up to Panicle initiation stage & 0.79 & 2.53 & 2.74 & 3.58 & 1.78 \\
\hline 54 & 0.65 & 2.15 & 1.22 & 1.63 & 1.51 \\
\hline 58 & 0.77 & 2.35 & 2.79 & 2.96 & 1.56 \\
\hline 62 & 0.45 & 2.34 & 2.71 & 2.97 & 1.35 \\
\hline Average flux up to Reproductive stage & 0.62 & 2.28 & 2.24 & 2.52 & 1.47 \\
\hline 66 & 0.38 & 1.82 & 2.63 & 2.78 & 1.24 \\
\hline 70 & 0.31 & 1.12 & 2.31 & 2.66 & 0.65 \\
\hline Average flux up to Ripening stage & 0.35 & 1.47 & 2.47 & 2.72 & 0.95 \\
\hline 74 & 0.18 & 1.31 & 1.86 & 0.18 & 0.48 \\
\hline 78 & 0.58 & 1.4 & 1.64 & 0.51 & 0.6 \\
\hline 82 & 0.39 & 0.84 & 1.56 & 0.56 & 0.21 \\
\hline Average flux up to Maturity stage & 0.38 & 1.18 & 1.69 & 0.42 & 0.43 \\
\hline Over all average & 0.57 & 1.87 & 2.37 & 3.52 & 1.27 \\
\hline
\end{tabular}




\section{Int.J.Curr.Microbiol.App.Sci (2017) 6(4): 423-430}
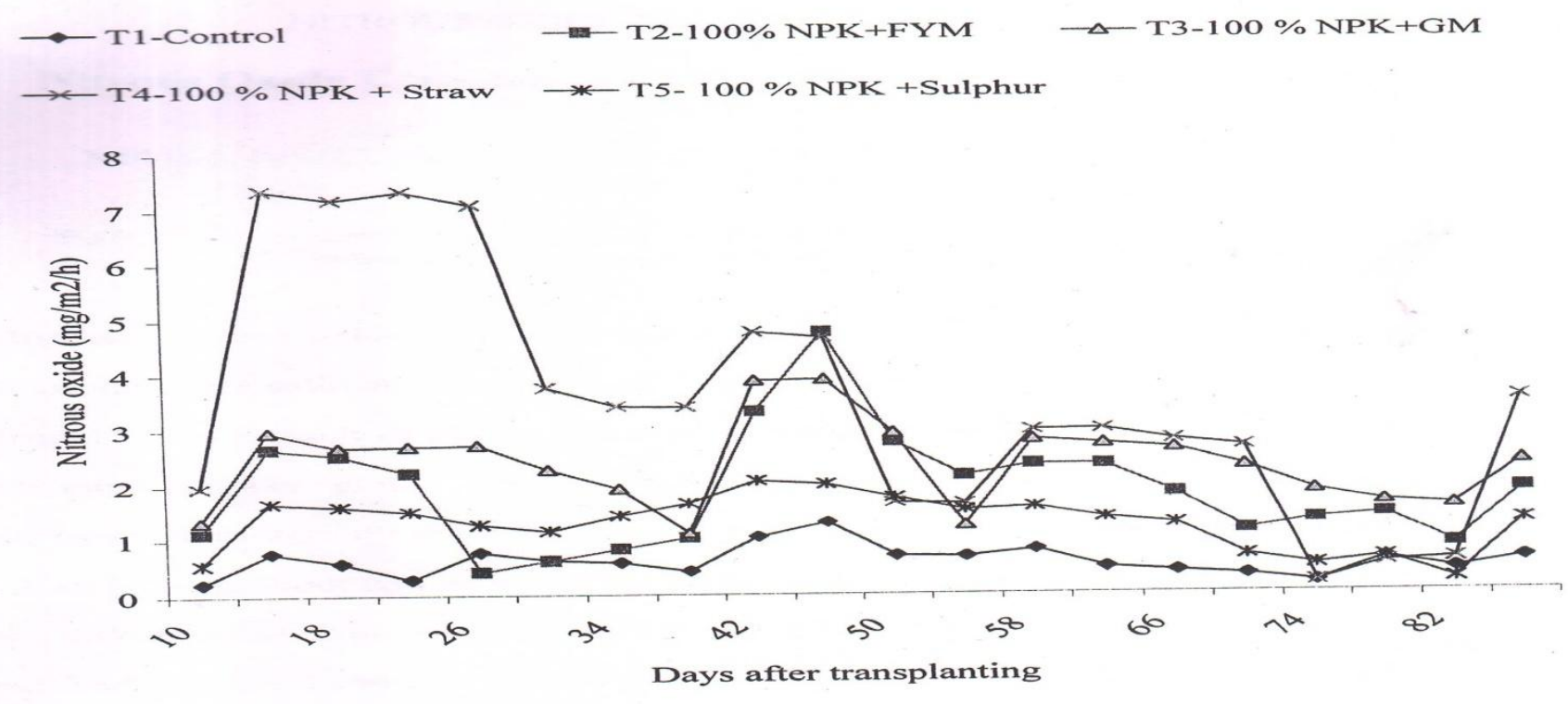

Figure 1. Nitrous oxide flux in rice as affected by different treatments 
At ripening and maturity the higher nitrous oxide emission in green manure and FYM treated plots is mainly due to the availability of more mineralized nitrogen after the decomposition of this organic amendment. However, at maturity stage the nitrous oxide emission in straw treated plot is mainly because of exhaustion of nitrogen provided by the straw to the soil. The result showed that nitrous oxide emission was strongly influenced by application of chemical fertilizers (Chen et al., 2002). Seasonal average fluxes of $\mathrm{N}_{2} \mathrm{O}$ varied between 0.03 mg $\mathrm{N}_{2} \mathrm{O}-\mathrm{N} \mathrm{m}^{-2} \mathrm{~d}^{-1}$ under continuous flooding and $5.23 \mathrm{mg} \mathrm{N}_{2} \mathrm{O}-\mathrm{N} \mathrm{m}^{-2} \mathrm{~d}^{-1}$ under the water regime of F-D-F-M. Both crop residueinduced $\mathrm{CH}_{4}$, ranging from 9 to $15 \%$ of the incorporated residue $\mathrm{C}$, and $\mathrm{N}_{2} \mathrm{O}$, ranging from 0.01 to $1.78 \%$ of the applied $\mathrm{N}$, were dependent on water regime in rice paddies. Estimations of net global warming potentials (GWPs) indicate that water management by flooding with midseason drainage and frequent water logging without the use of organic amendments is an effective option for mitigating the combined climatic impacts from $\mathrm{CH}_{4}$ and $\mathrm{N}_{2} \mathrm{O}$ in paddy rice production (Zou et al., 2005). The nitrous oxide fluxes were higher during initiation period of crop growth the availability of mineral nitrogen was high. Then, there was a decrease in fluxes during late tillering stage and early panicle initiation stage. The nitrous oxide fluxes increase again when the top dressing of split dose of fertilizers was done. The nitrous oxide emission was reduced by use of sulphurus fertilizers. This was also reported by (Bufogle et al., 1998). The results also indicated that nitrous oxide emission was enhanced undecomposed organic amendment (straw and green manure) as compared to welldecomposed organic amendment (farmyard manure) and sulphurus fertilizers. The additions of split doses of nitrogen also influenced the nitrous oxide emission. Therefore, the timing of nitrogen application should match the periods when plant requirement of nitrogen is highest. The midseason drainage and the multiple drainage, with $6.9 \%$ and $11.4 \%$ reduction in rice yield respectively, had an average methane emission per crop $27 \%$ and $35 \%$ lower when compared to the local method. Draining with fewer drain days during the flowering period was recommended as a compromise between emissions and yield. The field drainage can be used as an option to reduce methane and nitrous oxide emissions from rice fields with acceptable yield reduction. Mid-season drainage during the rice flowering period, with a shortened drainage period ( 3 days), is suggested as a compromise between the need to reduce global warming and current socioeconomic realities (Touprayoon et al., 2005).

\section{Acknowledgement}

The authors are thankful to the Head, Department of Agromateorology, G.B. pant University of Agriculture and Technology, Pantnagar, Uttarakhand for providing necessary facilities to conduct this research work.

\section{References}

Bufogle, A., Bollich, P.K., Kovar, J.L., Lindau, C.W. and Macchiavellied, R.E. 1998. Comparison of Ammonium sulphate and urea as nitrogen sources in rice production. J. Plant Nutr., 21(8): 1601-1614.

Chen, X., Cabrera, M.L., Zhang, L., Wu, J., Shi, X., Yu, W.T. and Shen, S.M. 2002. Nitrous oxide emission from upland crops soil systems in northeastern China. Nutr. Cyc. Agro Eco., 62(3): 241-247.

Hutchinson, G.L. and Mosier, A.R. 1981. Improved soil cover method for measurement of Nitrous oxide flux. Soil sci. Soc. Amer. J., 45: 311-316. 
IPCC. Climate change 2001. The scientist basis. Contribution of working Group I to the Third Assessment Report of the Inter-governmental panel on Climate Change. Cambridge University press Cambridge.

Mitra, S., Jain, M.C., Kumarm, S., Bandyopadhyay, S.K., and Kalra, N. 1999. "Effect of rice culticars on methane emission". Agri. Eco. Env., 73: $177-183$.

Robertson, G.P and J.M. Tiedje. 1987. Nitrous oxide sources in aerobic soil: Nitrification, denitrification and other biological processes. Soil Bio. and Bioche., 19: 187-193.

Tortoso, A.C. and G.L. Hutchinson. 1990.
Contributions of autotrophic and heterotrophic nitrifiers to soil $\mathrm{NO}$ and $\mathrm{N}_{2} \mathrm{O}$ emissions. Applied Env. Micro., 56: 1799-1805.

Towprayoon, S., Smakgahn, K. and Poonkaew, S. 2005. Mitigation of methane and nitrous oxide emissions from drained irrigated rice fields. Chemosphere, 59(11): 1547-1556.

Zou, Jianwen, Huang, Yao, Jiang, Jingyan, Zheng, Xunhua and Sass, Ronald L. 2005. A 3-year field measurement of methane and nitrous oxide emissions from ricpaddies in China: Effects of water regime, crop residue, and fertilizer application. Global Biogeochemica Cycles, 19: 2.

\section{How to cite this article:}

Singh, P.P., Rashmi Pawar and Meena, R. 2017. A Study of Nitrous oxide Emission from Rice Fields in Tarai Region of Uttarakhand, India. Int.J.Curr.Microbiol.App.Sci. 6(4): 423-430. doi: https://doi.org/10.20546/ijcmas.2017.604.048 